\title{
PENGARUH TUGAS PERKEMBANGAN KELUARGA TERHADAP PERKEMBANGAN SOSIAL ANAK USIA PRA SEKOLAH DI PUSKESMAS SP-3 WADIO KABUPATEN NABIRE
}

\author{
Angelia Adii ${ }^{1}$, Viertianingsih Patungo ${ }^{1}$,Marthinus Tame ${ }^{1}$ \\ ${ }^{1}$ Prodi S1 Keperawatan STIKES Jayapura \\ ${ }^{23}$ Dosen Keperawatan STIKES Jayapura \\ email:patungoviertianingsih@gmail.com
}

\begin{abstract}
ABSTRAK
Perkembangan anak pada usia prasekolah berpengaruhterhadap perkembangan pada periode berikutnya hingga anak menjadi dewasa.Anakbelajar mengenai berbagai hal termasuk dalam mengembangkan kemampuan motorik, kognitif,bahasa, serta sosial emosional. Salah satu aspek yang perlu diperhatikan yaitu perkembangan sosial emosional, sehingga dibutuhkan tugas keluarga dalam perkembangan anak yang baik. Tujuan penelitian ini untuk mengetahui pengaruh tugas perkembangan keluarga terhadap perkembangan sosial anak usia pra sekolah (family with preschool) di Puskesmas SP-3 Wadio Kabupaten Nabire. Metode penelitian berupa penelitian dengan metode korelasi dengan pendekatan cross sectional study di Puskesmas SP-3 Wadio pada 39 responden ibu yang dilaksanakan pada bulan Juni sampai Agustus 2019. Data diperoleh menggunakan kuesioner yang dianalisis menggunakan uji chi square. Hasil penelitian menunjukkan tugas perkembangan keluarga anak pra sekolah di Puskesmas SP-3 Wadio Kabupaten Nabire didapatkan pada kategori kurang sebanyak 10 orang $(25,6 \%)$ dan kategori baik sebanyak 29 orang $(74,4 \%)$. Perkembangan sosial anak kategori negatif sebanyak 11 orang $(28,2 \%)$ dan kategori positif sebanyak 28 orang $(71,8 \%)$. Ada hubungan tugas perkembangan keluarga terhadap perkembangan sosial anak pra sekolah di Puskesmas SP-3 Wadio Kabupaten Nabire ( $p$-value $=0,000)$. Kesimpulan penelitian yaitu ada pengaruh tugas perkembangan keluarga terhadap perkembangan sosial anak pra sekolah di Puskesmas SP-3 Wadio Kabupaten Nabire. Saran bagi orang tua untuk dapat membentuk perkembangan sosial anak dengan berkomunikasi kepada anaknya agar lebih meningkatkan kepercayaan diri anak, sehingga perkembangan sosial anak memberikan banyak kegiatan yang positif agar belajar berinteraksi sosial dan mandiri yang pada akhirnya dapat hidup bermasyarakat dengan baik.
\end{abstract}

Kata kunci: Tugas Perkembangan, Keluarga, Anak Pra Sekolah

\begin{abstract}
Children development at preschool age affects on development in the next period until the child becomes an adult. by learning about various things including in developing their motor, cognitive, language, and social emotional. One aspect that needs attention is social emotional, it takes a family task in developing a good child. Research objectives to study how to develop families towards the social development of preschool- aged children at the Wadio SP-3 Community Center in Nabire Regency.This type of research method was carried out with a cross sectional study that was placed in the Wadio SP-3 Puskesmas in 39 respondent mothers conducted in June to August 2019. Data obtained using a questionnaire were analyzed using the chi square test. The results shows that the task of developing children's families at the SP-3 Puskesmas Wadio Nabire District received a total of 10 people $(25.6 \%)$ and a good 29 people $(74.4 \%)$. The social development of children in the negative category is 11 people (28.2\%) and the positive category is 28 people (71.8\%). There is a relationship of the task of family development to the social development of school children at the Wadio SP-3 Community Center in Nabire Regency ( -value =0,000). The conclusion is there was a relationship of family development tasks to the social development of school children in Wadio SP-3 Community Center, Nabire Regency. The suggestion is parents can make social development by
\end{abstract}


encouraging in order to increase self-confidence, increase social development and provide a variety of positive activities in order to learn to develop socially and independently that can develop community life well.

Keywords: Development Task, Family, Pre School Children

\section{PENDAHULUAN}

Perkembangan anak pada usia prasekolah disebut sebagai masa emas "Golden Age" yang artinya perkembangan pada usia ini sangat berpengaruh terhadap perkembangan pada periode berikutnya hingga anak menjadi dewasa. Umumnya pada tahap ini anak usia dini belajar mengenai berbagai hal termasuk dalam mengembangkan kemampuan motorik, kognitif, bahasa, serta personal sosial mereka. Salah satu aspek yang perlu diperhatikan yaitu personal sosial (Pratiwi, 2018).

Pada tahap usia pra sekolahanak berada pada fase inisiatif versusrasa bersalah akibat kemapuannya yang terbatas. Pada masa ini anak dengan segala kecakapannya anak mulai berinteraksi dengan lingkungan sekitarnya sehingga menimbulkan rasa ingintahu terhadap segala hal yang dilihatnya. Mereka mencoba melakukan beberapa kegiatan, tetapi karena kemampuan anak tersebut terbatas adakalanya ia mengalami kegagalan, dan kegagalankegagalan tersebut menyebabkan anak memiliki perasaan bersalah dan untuk sementara waktu diatidak mau berinisatif atau berbuat (Indanah, 2019).

Menurut data Profil Kesehatan Kemenkes Republik Indonesia 2017), jumlah anak prasekolah sebanyak 9.451 .943 jiwa atau sekitar $(3,7 \%)$ dan sebanyak85,779 $(62,02 \%)$ anak usia prasekolah mengalami gangguan perkembangan. Sedangkan menurut data Ikatan Dokter Indonesia (IDAI, 2017) terdapat anak sebanyak 5-10\% diperkirakan mengalami keterlambatan perkembangan. Menurut Data Dinas Kesehatan Provinsi Papua (2017) data keterlambatan perkembangan anak mencapai 2-5\% dan Data Dinas Kesehatan Kabupaten Nabire mencapai 3-5\% (Dinkes Kabupaten Nabire, 2017). Pola asuh orang tua dalam tugas perkembangan keluarga adalah perlakuan atau sikap orang tua dalam berinteraksi dengan anak-anaknya untuk memenuhi kebutuhan, memberikan perlindungan, mendidik, membimbing anak dalam kehidupan sehari-hari (Setiani, 2017). Peran ibu dan ayah dapat memberikan pola pengasuhan yang benar kepada anak-anaknya agar anak dapat tumbuh dan berkembang secara optimal. Orang tua sangat berperan penting dalam kehidupan anak karena orang tua merupakan orang pertama dalam keluarga untuk mendidik, mengasuh, memberikan contoh yang baik agar anak dapat tumbuh dan berkembang secara optimal. Maka disini tugas orang tua dituntut untuk memberikan pola asuh yang tepat dan sesuai untuk usia anaknya (Putri, 2019).

Berdasarkan permasalahan tersebut, maka peneliti tertarik untuk melakukan penelitian tentang "Pengaruh tugas perkembangan keluarga terhadap Perkembangan Sosial Anak Usia Pra Sekolah (Family With Preschool) di Puskesmas SP-3 Wadio KabupatenNabire".

\section{METODE PENELITIAN}

Jenis penelitian ini dilakukan metode korelasi dengan pendekatan cross sectional study yang berlokasi di SP-3 Wadio Nabire Papua pada 39 Responden yang dilaksanakan pada bulan Juni sampai dengan Agustus 2019. Data diperoleh menggunakan kuesioner yang dianalisis menggunakan uji chi square.

\section{HASIL PENELITIAN}

\section{Karakteristik Orang Tua/Ayah}

Tabel 1 Distribusi Responden Berdasarkan Karakteristik Ayah/Orang Tua Wali Anak PraSekolah 


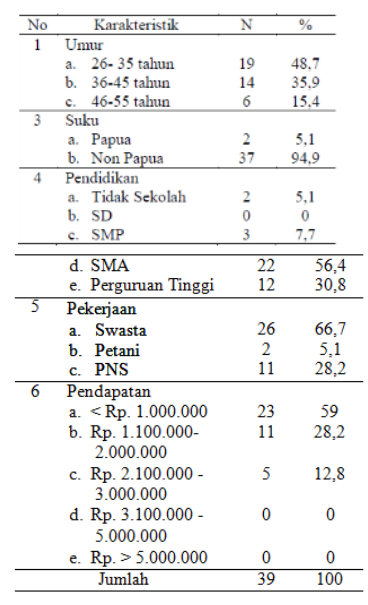

Berdasarkan Tabel 1 distribusi frekuensi ayah/orang tua wali anak pra sekolah di Puskesmas SP-3 Wadio Kabupaten Nabire didapatkan bahwa dari 39 responden terbanyak pada umur antara 26-35 tahun berujmlah 19orang $(48,7 \%)$, Non Papua sebanyak 37 orang $(94,9 \%)$, pendidikan SMA sebanyak 22 orang $(56,4 \%)$ dan bekerja sebagai swasta sebanyak 26 orang $(66,7 \%)$ dengan pendapatan keluarga terbanyak dengan pendapatan keluarga $<\mathrm{Rp}$. 1.000.000sebanyak 23 orang (59\%).

\section{Karakteristik anak}

Tabel 2 Distribusi Responden Berdasarkan Karakteristik Ibu/Orang Tua Wali Anak Pra Sekolah

\begin{tabular}{|c|c|c|c|}
\hline No & Karakteristik & $\mathrm{N}$ & $\%$ \\
\hline \multirow[t]{4}{*}{1} & Umur & & \\
\hline & a. 26- 35 tahun & 21 & 53,8 \\
\hline & b. $36-45$ tahun & 15 & 38,5 \\
\hline & a. 46-55 tahun & 3 & 7,7 \\
\hline \multirow[t]{3}{*}{3} & Suku & & \\
\hline & a. Papua & 2 & 5,1 \\
\hline & b. Non Papua & 37 & 94,9 \\
\hline \multirow[t]{6}{*}{4} & Pendidikan & & \\
\hline & a. Tidak Sekolah & 0 & 0 \\
\hline & b. $\mathrm{SD}$ & 5 & 12,8 \\
\hline & c. SMP & 16 & 41 \\
\hline & d. SMA & 18 & 46,2 \\
\hline & e. Perguruan Tinggi & 0 & 0 \\
\hline \multirow[t]{6}{*}{5} & Pekerjaan & & \\
\hline & a. Tidak kerja & 29 & 74,4 \\
\hline & b. Swasta & 10 & 25,6 \\
\hline & c. Petani & 0 & 0 \\
\hline & d. PNS & 0 & 0 \\
\hline & Jumlah & 39 & 100 \\
\hline
\end{tabular}

Berdasarkan Tabel 2 distribusi frekuensi ibu orang tua anak pra sekolah di Puskesmas SP3 WadioKabupaten Nabire didapatkan bahwa dari 39 responden terbanyak pada umur antara 26-35 tahun berjumlah 21 orang $(53,8 \%)$, suku non Papua sebanyak 37 orang $(94,4 \%)$, pendidikan SMA sebanyak 18 orang $(46,2 \%)$ dan sebagian besar tidak bekerja sebanyak 29 orang $(74,4 \%)$.

\section{Karakteristik Ibu}

Tabel 3 Distribusi Responden berdasarkan Karakteristik Anak Pra Sekolah

\begin{tabular}{llcc}
\hline $\mathbf{N}$ & \multicolumn{1}{c}{ Karakteristik } & $\mathrm{N}$ & $\%$ \\
\hline $\mathrm{O}$ & & & \\
\hline 1 & Umur & & \\
& a. $26-35$ tahun & 21 & 53,8 \\
& b. $36-45$ tahun & 15 & 38,5 \\
& a. $46-55$ tahun & 3 & 7,7 \\
\hline 3 & Suku & & \\
& a. Papua & 2 & 5,1 \\
& b. Non Papua & 37 & 94,9 \\
\hline 4 & Pendidikan & & \\
& a. Tidak Sekolah & 0 & 0 \\
& b. SD & 5 & 12,8 \\
& c. SMP & 16 & 41 \\
& d. SMA & 18 & 46,2 \\
& e. Perguruan & 0 & 0 \\
& Tingai & & \\
\hline 5 & Pekerjaan & & \\
& a. Tidak kerja & 29 & 74,4 \\
& b. Swasta & 10 & 25,6 \\
& c. Petani & 0 & 0 \\
& d. PNS & 0 & 0 \\
\hline & Jumlah & 39 & 100 \\
\hline
\end{tabular}

Berdasarkan Tabel 3 distribusi frekuensi karakteristik anak pra sekolah di Puskesmas SP-3 Wadio Kabupaten Nabire didapatkan dari 39 responden, terbanyak berumur 2,53,5 tahun sebanyak 20 orang $(51,3 \%)$, jenis kelamin perempuan sebanyak 21 orang $(53,8 \%)$ dan terbanyak merupakan anak pertama sebanyak16orang $(41 \%)$

\section{Tugas Perkembangan Keluarga}

Tabel 4 Distribusi frekuensi berdasarkan tugas perkembangan keluarga

\begin{tabular}{cccc}
\hline No & $\begin{array}{c}\text { Tugas } \\
\text { perkembanga } \\
\text { nkeluarga }\end{array}$ & N & $\%$ \\
\hline 1 & $\begin{array}{l}\text { Kurang } \\
\text { Baik }\end{array}$ & 10 & 25,6 \\
\hline & Jumlah & 39 & 100 \\
\hline
\end{tabular}

Berdasarkan Tabel 4 distribusi frekuensi tugas perkembangan keluarga anak pra sekolah di Puskesmas SP-3 Wadio Kabupaten Nabire dari 39responden didapatkan sebanyak 10 orang $(25,6 \%)$ dengan tugas perkembangan keluarga kurang dan sebanyak 29 orang $(74,4 \%)$ dengan tugas perkembangan keluarga baik.

5. Perkembangan Sosial Anak

Tabel 5 Distribusi frekuensi perkembangan sosial anak pra sekolah di Puskesmas SP-3 Wadio Kabupaten Nabire

\begin{tabular}{cccc}
\hline No & $\begin{array}{c}\text { Perkembangan Sosial } \\
\text { Anak }\end{array}$ & N & $\%$ \\
\hline 1 & Negatif & 11 & 28,2 \\
2 & Positif & 28 & 71,8 \\
\hline & Jumlah & 39 & 100 \\
\hline
\end{tabular}

Berdasarkan Tabel 5 distribusi frekuensi perkembangan sosial anak di Puskesmas SP3 Wadio Kabupaten Nabire kategori negatif 
sebanyak 11 orang $(28,2 \%)$ dan kategori positif sebanyak 28 orang $(71,8 \%)$.

\section{Pengaruh Tugas perkembangan keluarga terhadap Perkembangan Sosial Anak Pra Sekolah}

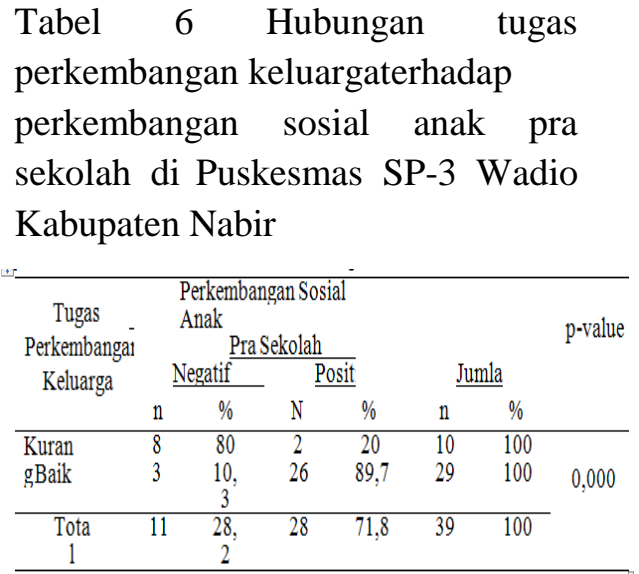

Hasil penelitian menunjukkan bahwa tugas perkembangan keluarga yang kurang memiliki anak dengan perkembangan sosial negatif sebanyak 8orang (80\%) dantugas perkembangan keluarga baik dengan perkembangan sosialpositifsebanyak 2 orang (20\%). Tugas perkembangan keluarga yang baik memiliki anak dengan perkembangan sosial positif sebanyak 3 orang $(10,3 \%)$ dan tugas perkembangan keluarga baik dengan perkembangan sosial positif sebanyak 26 orang $(89,7 \%)$. Hasil uji chi square diperoleh nilai $\mathrm{p}$-value $=0,000$ yang diartikan bahwa ada pengaruhtugas perkembangan keluarga terhadap perkembangan sosial anak pra sekolah di Puskesmas SP-3 Wadio Kabupaten Nabire.

\section{PEMBAHASAN}

Berdasarkan Tabel 1 distribusi frekuensi ayah/orang tua wali anak pra sekolah di Puskesmas SP-3 Wadio Kabupaten Nabire didapatkan bahwa dari 39 responden terbanyak pada umur antara 26-35 tahun berjmlah 19 orang $(48,7 \%)$ dan umur ibu antara 26-35 tahun berjumlah 21 orang $(53,8 \%)$. Hal ini menunjukkan bahwa umur orang tua menurut Depkes RI (2009) dalam kategori dewasa muda. Penelitian ini sejalan dengan penelitian yang dilakukan oleh Setiani (2017) di TK ABA Godegan Bantul yang mengungkapkan bahwa sebagain besar umur orang tua anak berada pada rentang usia dewasa muda. Rentan usia orangtua sangat menentukan pola pengasuhan. Apabila usia orang tua terlalu muda atau tua mungkin tidak dapat menjalankan peran tersebut secara optimal karena diperlukan kekuatan fisik dan psikologis.Orang tua usia muda lebih cenderung akan menerapkan pola asuh demokratis dan permisif kepada anak-anaknya karena lebih bisa terbuka dan dapat berkomunikasi dengan baik. Sedangkan pasangan usia tua lebih cenderung menerapkan pola asuh otoriter kepada anakanaknya karena merasa lebih berpengalaman dalam memberikan pengasuhan pada anakanaknya (Setiani, 2 Hal ini juga didukung penelitian Wulandari (2016), yang mengatakan bahwa umur orang tua mempunyai kaitan erat dengan tingkat kedewasaan seseorang yang berarti kedewasaan teknis dalam arti keterampilan melaksanakan tugas maupun kedewasaan psikologis orang tua untuk mengurus anak.

Suku orang tua anak pra sekolah di Puskesmas SP-3 Wadio Kabupaten Nabire sebagian berasar berasal dari suku Non Papua sebanyak $(94,9 \%)$ dan sedikit berasal dari Suku Papua $(5,1 \%)$. hal ini disebabkan wilayah kerja Puskesmas SP-3 Wadio Kabupaten Nabire merupakan daerah transmigrasi yang berasal dari luar daerah Papua. Pendidikan orang tua ayah sebagian besar adalah SMA $(56,4 \%)$ dan ibu dengan pendidikan SMA $(46,2 \%)$. Pendidikan orang tua akan berdampak pada pekerjaan orang tua, dimana pekerjaan ayah $66,7 \%$ bekerja di sektor swasta dan sebagian besar ibu tidak bekerja $(74,4 \%)$. Hal ini berpengaruh terhadap pendapatan orang tua, dimana rata - rata pendapatan keluarga <Rp. 1.000.000 sebanyak 23 orang $(59 \%)$. Ibu yang tidak bekerja lebih memiliki waktu dalam merawat dan mengawasianaknya.Dalam penelitian Rokhman (2016), dijelaskanbahwa ibu yang tidak bekerja memiliki waktu kebersamaan antara ibu dan anak. Artinya semakin banyak waktu untuk bersama menyebabkan kesempatan untuk melakukan stimulasi pertumbuhan dan perkembangan pada anak juga semakinbaik Septiari (2012) mengungkapkan bahwa faktor yang mempengaruhi pola asuh dalam tugas keluarga adalah pekerjaan, pendidikan dan sosial ekonomi. Orang tua yang berpendidikan tinggi umumnya mengetahui bagaimana tingkat perkembangan anak khususnya untuk pembentukan kepribadian yang baik bagi anak, 
dapat mengajarkan sopan santun kepada orang lain dibandingkan dengan orang tua yang berpendidikan rendah. Selain itu, orang tua yang tingkat perekonomiannya menengah ke bawah dalam cara pengasuhannya memang kurang dapat memenuhi kebutuhan anak yang bersifat materi. Orang tua hanya dapat memenuhi kebutuhan yang benar-benar penting bagi anak. Perhatian dan kasih sayang orang tualah yang dapat diberikan. Anak yang hidup dalam perekonomian menengah ke bawah terbiasa hidup dengan segala kekurangan yang dialami keluarga, sehingga akan terbentuk kepribadian anak yang, mandiri, mampu menyelesaikan permasalahan, dan tidak mudah stres dalam menghadapi suatu permasalahan dan anak dapat menghargai usaha orang lain. Penelitian ini sejalan dengan Setiani (2017) bahwa semakin tinggi tingkat pendidikan orang tuasemakin mudah menerima informasi sehingga pengetahuan orang tua semakin luas, sebaliknya jika pendidikan orang tua kurang akan menghambat informasiyang didapatkan, dan jarang mendapat informasi yang berhubungan dengan tumbuh kembang anak.

Karakteristik anak pra sekolah di Puskesmas SP-3 Wadio Kabupaten Nabire didapatkan berumur 2,5-3,5 tahun (51,3\%), jenis kelamin perempuan $(53,8 \%)$ dan terbanyak merupakan anak pertama sebanyak 16 orang (41\%). Penelitian ini sejalan dengan penelitian yang dilakukan Indahan (2019) di Desa Kramat Kecamatan Dempet Kabupaten Demak yang menemukan anak usia pra sekolah lebih banyak pada usia 3 tahun.

Tugas perkembangan keluarga adalah salah satu faktor dan aspek penting yang dapat mendukung perilaku anak untuk berprestasi. Tugas perkembangan keluarga juga berpengaruh terhadap pengembangan intelektual anak,termasuk pengembangan motivasi berprestasi anak. Pola kepemimpinan orang tua juga merupakan faktor penting dalam mempengaruhi munculnya individu berprestasi.Apabila tugas perkembangan keluarga dapat menunjang motivasi berprestasi yang tinggi, tentu prestasi belajar anak jugaakan tinggi. Selain dorongan dari luar motivasi berprestasi juga bisa tumbuh dari dalam diri individu itu sendiri (Susanto, 2013).

Hasil penelitian diperoleh bahwa tugas perkembangan keluarga anak pra sekolah di Puskesmas SP-3 Wadio Kabupaten Nabire dari 39 responden didapatkan sebanyak 10 orang $(25,6 \%)$ dengan tugas perkembangan keluarga kurang dan sebanyak 29 orang $(74,4 \%)$ dengan tugas perkembangan keluarga baik. Hal ini menunjukkan bahwa sebagian besar keluarga memiliki tugas perkembangan keluarga yang baik.

Hasil penelitian ini sejalan dengan penelitian Yulita (2014), bahwa sebagian besar orang tua memiliki tugas perkembangan keluarga yang positif. Hal ini disebabkan orang tua menginginkan anaknya kelak menjadi orang berguna dan curahan kasih sayang diberikan orang tua kepada anaknya (Yulita, 2014).

Adapun tugas perkembangan keluarga yang baik pada anak pra sekolah di Puskesmas SP-3 Wadio karena anak orang tua melihat dan memberlakukan anak sebagai titipan dari Tuhan Yang Maha Esa Saya mengasuh dan mengembangkan anak supaya anak menjadi dirinya sendiri. Orang tua menghormati dan mendukung tindakan yang dilakukan anaknya dan selalu fokus untuk mencari solusi dari permasalahan anak dengan membimbing anak kepada hal-hal yang bermanfaat serta mendidik anak agar belajar dari kesalahan dan melibatkan anak untuk mencari jalan keluar terbaik.

Tugas perkembangan keluarga positif adalah tugas perkembangan keluargayang diberikan orang tua kepada anak dengan menumbuhkan konsep dan pemikiran yang positif serta sikap menghargai diri sendiri. Dan dikatakan tugas perkembangan keluarga kurang adalah bila orang tua sering melakukan hal-hal yang negatif, seperti suka memukul, mengabaikan, kurang memperhatikan, melecehkan, menghina, bersikap tidak adil, tidak pernah memuji, suka marah- marah,dan sebagainya yang dianggap sebagai hukuman akibat kekurangan, kesalahan atau pun kebodohan dirinya (Muthmainnah, 2012).

Tugas perkembangan keluarga yang kurang karena orang tua sangat melindungi dan tidak memberikan kepercayaan kepada anak (Over protective), di mana orang tua tidak memberi kesempatan kepada anak untuk mengungkapkan perasaannya. Selain itu orang tua selalu mengikuti keinginan anak. Hal ini akan menyebabkan perkembangan sosial anak akan terganggu. Hal ini disebabkan orang tua selalu membuat keputusan sendiri tanpa memikirkan pendapat anak karena merasa khawatir atau takut jika anaknya terjadi apa - apa. Orang tua juga tidak segan memarahi anak, jika anak berperilaku tidak sesuai dengan keinginan orang tua dan 
mempunyai persepsi bahwa kecerdasan intelektual adalah faktor utama yang akan membuat anak sukses (Muthmainnah, 2012) Tugas perkembangan keluarga kurang yang dilakukan orang tua tampak orang tua menerapkan tugas perkembangan keluarga otoriter dan permisif. Pada satu sisi anak tidak diberikan kebebasan sehingga mengikuti keinginan orang tua, disi lain ada orang tua yang membebaskan anaknya sehingga anak kurang terbimbing dalam menghadapi lingkungan sosial anak. Peneliti berasumsi bahwa tugas perkembangan keluargayang negatif akan membawa suasana anak kedalam suasana yang tidak menyenangkan, sehingga akan menghambat perilaku sosialnya kepada orang lain atau teman sebayanya.

Menurut Adek (2008) dalam Suharsono (2012), tugas perkembangan keluarga otoriter akan menghasilkan karakteristik anak yang penakut, pendiam, tertutup, tidak berinisiatif, gemar menentang, suka melanggar norma, berkepribadian lemah, cemas, dan menarik diri. Tugas perkembangan keluargaini akan menghasilkan anak dengan tingkahlaku pasif dan cenderung menarik diri.Sikap orang tua yang keras akan menghambat inisiatif anak.

Menurut Lutvita dalam Fitriani (2012), anak yang diasuh secara permisif mempunyai kecenderungan kurang berorientasi pada prestasi, egois, suka memaksakan keinginannya, kemandirian yang rendah, serta kurang bertanggungjawab. Anak juga akan berperilaku agresif dan antisosial, karena sejak awal tidak diajarkan untuk mematuhi peraturan sosial, tidak pernah diberi hukuman ketika melanggar peraturan yang telah ditetapkan orang tua.

Ditinjau dari pekerjaan orang tua, sebagian besar tugas perkembangan keluarga positif yang dilakukan orang tua pada ayah yang bekerja sebagai petani dan PNS dan ibu yang tidak bekerja. Hal ini terkait dengan pendidikan ibu yang sebagian besar dengan pendidikan SD dan SMP. Dari hasil penelitian ini bahwa semua anak diasuh oleh kedua orang tuanya.

Menurut Septiari (2012), faktor yang mempengaruhi tugas perkembangan keluarga dari latar belakang pendidikan orang tua mempunyai pengaruh yang besar terhadap pembentukan kepribadian anak. Orang tua yang berpendidikan tinggi umumnya mengetahui bagaimana tingkat perkembangan anak khususnya untuk pembentukan kepribadian yang baik bagi anak, dapat mengajarkan sopan santun kepada orang lain, baik dalam berbicara ataupun dalam hal lain. Orang tua yang mempunyai latar belakang pendidikan rendah, dalam pengasuhan anak umumnya orang tua kurang memperhatikan tingkat perkembangan anak. Hal ini dikarenakan orang tua yang masih awam, dan tidak mengetahui tingkat perkembangan anak.

Perkembangan sosial anak adalahproses perubahan yang berlangsung secaraterus menerus menuju kedewasaan yangmemerlukan adanya komunikasi denganmasyarakat (Yuliastanti, 2014). Selanjutnya menurut Wiyani (2015), perkembangan sosial adalah perubahan terkait dengan kemampuan dalam menjalin relasi dengan dirinya sendiri maupun dengan orang lain untuk mendapatkan keinginannya atau keterkaitan antara sosial dan emosional.

Hasil penelitian diperoleh bahwa perkembangan sosial anak di Puskesmas SP-3 Wadio Kabupaten Nabire kategori negatif sebanyak 11 orang $(28,2 \%)$ dan kategori positif sebanyak 28 orang $(71,8 \%)$.Hal ini menunjukkan bahwa perkembangan sosial anak sebagian besar positif.

Hasil penelitian ini sejalan dengan penelitian Putri (2012), bahwa sebagian besar anak memiliki kemampuan sosial positif dengan berinteraksi sosial yang baik dengan temantemannya,orang tua dan guru. Sedangkan anak dengan perkembangan sosialnya negatif cenderung tertutup dan kurang berinteraksi dengan teman- temannya.

Perkembangan anak yang positif pada anak pra sekolah di Puskesmas SP-3 Wadio, dimana anak dapat berinteraksi dengan mengajak temannya bermain dan memiliki kepribadian yang baik dengan meminta izin bila menggunakan benda milik temannya dandapat berkomunikasi dengan orang - orang yang ditemuinya. Selain itu, anak memiliki rasa 
percaya diri dan memiliki kemandirian yang baik dengan mengurus dirinya sendiri. Selain itu, anak disiplin dalam bermain dan merapihkannya setelah bermain. Tentunya hal ini perlu adanya dorongan dari orang tua dalam mengajarkan anak-anaknya. Perkembangan anak yang negatif, karena anak tidak dapat bersosialisasi dengan baik kepada temannya maupun dengan orang lain, serta tidak mandiri dan disiplin dan mengikuti keinginannya sendiri atau tidak mau mengalah pada temannya(Septiary, 2012).

Adanya tugas perkembangan keluarga yang baik pada anak pra sekolah akan memberikan dampak kelanjutanya di mana anak yang kemampuansosialnya positif akan lebih mudah bergaul dan mempengaruhi interaksi sosial kepada temannya dan mempengaruhi prestasi anak. sedangkan anak dengan perkembangan negatif akan sangat berisiko di kemudian hari bila tidak ditangani dengan segera oleh orang tua yang berdampak pada perilaku yang buruk pada lingkungan sekitarnya.

Hasil penelitian diperoleh bahwa ada pengaruh tugas perkembangan keluarga terhadapperkembangan sosial anak pra sekolah di Puskesmas SP-3 Wadio Kabupaten Nabire ( $p$ value $=0,000)$. Hal ini menunjukkan adanya korelasi yang positif antara tugas perkembangan keluarga terhadap perkembangan sosial anak, dimana tugas perkembangan keluarga yang semakin baik, perkembangan sosial anak akansemakin baik.

Hasil penelitian sejalan dengan penelitian yang dilakukan oleh Amelia (2014), bahwa ada hubungan tugas perkembangan keluarga dengan perkembangan sosial dan bahasa anak. Hal ini disebabkan anak dapat berinteraksi dan berkomunikasi dengan baik pada temantemannyadan lingkungan sekitarnya.

Sedangkan anak yang mendapatkan tugas perkembangan keluarga kurang, namun memiliki anak dengan perkembangan sosial yang positif disebabkan ada faktor lain yang mempengaruhi selain pola asuh. Menurut Wiyani (2015), faktor - faktor yang mempengaruhi perkembangan sosial anak terbagi dalam tiga bagian, yaitu faktor hereditas, faktor lingkungan dan faktor umum digolongkan ke dalam kedua faktor faktor hereditas dan lingkungan.

Umumnya anak memiliki pola pertumbuhan dan perkembangan normal yang merupakan hasil dari banyak faktor yang mempengaruhi pertumbuhan dan perkembangan anak tersebut. Terdapat banyak faktor yang dapat membuat orang tua memiliki pola asuh, beberapa faktor yang dapat mempengaruhi orang tua dalam memilih pola asuh, yaitu hereditas atau keturunan serta lingkungan (Hurlock, 2003 dalam Amelia 2014).

Adanya tugas perkembangan keluarga yang positif dari orang tua secara presentatif lebih tinggi memiliki anak dengan perkembangan sosial yang positif dibandingkan perkembangan sosial negatif. Hal ini menunjukkan bahwa tugas perkembangan keluarga berkorelasi positif dan memiliki hubungan yang kuat pengaruhnya terhadap perkembangan sosial anak. semakin baik orang tua mengasuh anaknya dengan positif, semakin baik perkembangan sosial anak yang positif. Sebaliknya bila tugas perkembangan keluargaorang tua yang negatif akan berdampak pada perkembangan sosial anak yang negatif.

\section{KESIMPULAN}

Berdasarkan hasil pembahasan dapat disimpulkansebagai berikut:

Karakteristik ayah/orang tua wali anak pra sekolah di Puskesmas SP-3 Wadio Kabupaten Nabire didapatkan terbanyak pada umur antara 26-35 tahun berjmlah 19 orang $(48,7 \%)$, Non Papua sebanyak 37 orang $(94,9 \%)$, pendidikan SMA sebanyak 22 orang $(56,4 \%)$ dan bekerja sebagai swasta sebanyak 26 orang $(66,7 \%)$ dengan pendapatan keluarga terbanyak dengan pendapatan keluarga $<$ Rp.1.000.000 sebanyak 23 orang (59\%). Karakteristik ibu orang tua anak pra sekolah di Puskesmas SP-3 Wadio Kabupaten Nabire didapatkan bahwa dari 39 responden terbanyak pada umur antara 26-35 tahun berjumlah 21 orang $(53,8 \%)$, suku non Papua sebanyak 37 orang $(94,4 \%)$, pendidikan SMA sebanyak 18 orang $(46,2 \%)$ dan sebagian besar 
tidak bekerja sebanyak 29 orang $(74,4 \%)$.

1. Karakteristik anak berumur 2,5-3,5 tahun sebanyak 20 orang $(51,3 \%)$, jenis kelamin perempuan sebanyak 21 orang $(53,8 \%)$ dan terbanyak merupakan anak pertama sebanyak 16 orang $(41 \%)$.

2. Tugas perkembangan keluarga anak pra sekolah di Puskesmas SP-3 Wadio Kabupaten Nabire didapatkan sebanyak 10 orang $(25,6 \%)$ dengan tugas perkembangan keluarga kurang baik dan sebanyak 29 orang $(74,4 \%)$ dengan tugas perkembangan keluarga baik.

3. Perkembangan sosial anak di Puskesmas SP-3 Wadio Kabupaten Nabire kategori negatif sebanyak 11 orang $(28,2 \%)$ dan kategori positif sebanyak 28 orang $(71,8 \%)$.

4. Ada pengaruhtugas perkembangan keluarga terhadap perkembangan sosial anak pra sekolah diPuskesmas SP-3 Wadio Kabupaten Nabire ( $p$-value $=0,000)$.

\section{Saran}

1. Bagi Pihak Puskesmas

Tenaga kesehatan dapat memberikan penyuluhan tentang tugas perkembangan keluarga yang baik kepada orang tua dengan cara menstimulasi anak, sehingga perkembangan sosial anak dapat optimal.

2. Bagi Keluarga

a. Masyarakat khususnya keluarga dapat menggunakan tugas perkembangan keluarga yang tepat untuk mendidik anak, yang disesuaikan dengan masalah yang adapada anak usia sekolah.

b. Keluarga mampu meningkat rasa asah asih asuh kepada anak agar anak bisa dekat dengan orang tua, mandiri dalam melakukan segala kegiatan(aktivitas) Orang tua dapat membentuk perkembangan sosial anak dengan berkomunikasi kepada anaknya agar lebih meningkatkan kepercayaan diri anak, sehingga perkembangan sosial anak memberikan banyak kegiatan yang positif agar belajar berinteraksi sosial dan mandiri yang pada akhirnya dapat hidup bermasyarakat dengan baik.

3. Bagi Peneliti

Dapat menjadi acuan dalam pelayanan terkait dengan perkembangan sosial anak dengan memberikan penyuluhan kepada orang tua tentang pentingnya tugas perkembangan keluarga.

4. Bagi Peneliti Selanjutnya

Perlu dilakukan penelitian yang lebih lanjut, dengan melakukan observasi langsung pada anak terkait dengan perkembangan sosial anak dan metode penelitian yang lain.

\section{DAFTAR PUSTAKA}

Cahyaningsih D. S. (2011). Pertumbuhan Perkembangan Anak dan Remaja. Jakarta: TIM.

Cahyono, A. D. (2017). Pengaruh Stimulasi Orang tua terhadap Perkembangan Sosial Anak Usia Toddler. Jurnal AKP, 5 (1), 3-6 Dompas, R (2010). Ilmu Kesehatan Anak.Jakarta: EGC.

Harmoko, 2012. Asuhan Keperawatan Keluarga,Yogyakarta: Pustaka Pelajar.

Helmawati. 2014. Pendidikan Keluarga Teoritis dan Praktik. Bandung: PT Remaja Rosdakarya.

Herlina, 2013. Hubungan Pola Asuh Keluarga

Dengan Kemandirian Perawatan Diri Anak Usia Sekolah Di Kelurahan

Cisalak Pasar Kecamatan Cimanggis

Kota Depok. www.fik_ui.co.id. diakses

2 Februari 2019.

Pkl. 20.15 Wit

Indanah (2019). Perkembangan Sosial

Emosional Anak Usia Pra Sekolah.

Jurnal Ilmu Keperawatan dan

Kebidanan Vol.10 No.1 (2019) 221228. 221. 
IDAI (2017). Pertumbuhan dan Perkembangan Anak. http://www.idai.go.id. diakses 20 Februari 2019.Kemenkes RI (2017). Profil Kesehatan Indonesia.

http://www.kemenkesri.go.id. diakses 20Februari 2019.

Mahanani M (2015). Hubungan Perhatian Orang tua Dengan Perkembangan Sosial Anak Usia 4-5 Tahun Di Desa Birit Kecamatan Wedi Kabupaten Klaten Tahun 2015. Program Studi Pendidikan Luar Sekolah Jurusan Pendidikan Luar Sekolah Fakultas Ilmu Pendidikan Universitas Negeri Yogyakarta.

Marmi R (2012) PengantarPsikologi

Kebidanan.Buku Ajar Psikologi

Kebidanan Jakarta : Pustaka Pelajar. Muchtar M (2011) Psikologi perkembangan anak.

Jakarta: Erlangga.

Mulato A (2015), Hubungan Pol Asuh Orang

Tua Dengan Perkembangan Sosial

AnakRetadasi Mental di SLB

C YPSLBKartasura.

http://www.umud.surakarta.co.id. diakses 2Juni 2016.

Notoatmodjo S, 2012. Metode Penelitian Kesehatan. Jakarta: Rineka Cipta Padila (2013). Asuhan Keperawatan Keluarga. Yogayakarta: Nuha Medika Pratiwi I (2018). Pengaruh Playgroup Terhadap Perkembangan Personal Sosial Anak Prasekolah Winta. Program Studi Keperawatan Fakultas Ilmu Kesehatan Universitas Muhammadiyah Surakarta. Premana Yudi (2011). Hubungan Antara Pola Asuh Keluarga, Disiplin Belajar, dan Minat Belajar dengan Prestasi Belajat Teknologi Informasi dan Komunikasi (TIK)pada Anak Kelas VIII Semester Genap di SMP Negeri 3 Singaraja Tahun Ajaran 2010/2011. http://www.undiksha.co.id.diakses 2 Februari 2019 Pkl. 20.45 Wit.

Putri IA (2019). Hubungan Pola Asuh Orang Tua Bekerja Dengan Perkembangan
Anak Usia Prasekolah (4 - 5 Tahun) di Tk Gmim Bukit Moria Malalayang. Ejournal Keperawatan (e-Kp) Volume 7 No. 1

Februari 2019

Rahmawati F (2014) Hubungan Antara Pola

AsuhOrang Tua Dan Kebiasaan Belajar

Terhadap Prestasi Belajar Anak Sd

Kelas IV Semester Genap Di

Kecamatan Melaya-Jembrana.

http://www.ganesha.co.id.diakses 2

Februari 2019. Pkl. 20.45 Wit

Santoso dan Ranti, 2009. Kesehatan dan Gizi.

Jakarta: Rineka Cipta.

Saputra Lindon (2013). Pengantar Kebutuhan

Dasar Manusia. Tangerang: Bina Rupa

Aksara

Sari E. Y (2015) Pengaruh Pola Asuh Orang Tua Terhadap Prestasi Belajar Ips Anak Kelas $V$ SD Se-Gugus III Seyegan Sleman Tahun Ajaran 2014/2015.

http://www.universitaspgri.co.id. diakses 20

Februari 2019. Pkl. 20.45 Wit

Saryono dan Anggraeni M.D, 2010. Metodologi

Peneltiian Kualitatif dan Kuantitaif.

Yogyakarta : Nuha Medika.

Setiani WA (2017). Hubungan Pola Asuh

Orang tua Dengan Perkembangan

Personal Sosial di TK Aba Godegan

Bantul. Program Studi Ilmu

Keperawatan Sekolah Tinggi Ilmu

Kesehatan Jenderal AchmadYani

Yogyakarta 2017.

Sujiono Y. N (2013). Pendidikan Dasar Anak

Usia Dini. Jakarta: Indeks.

Sunarto (2013) Psikologi

Perkembangan Anak.

Jakarta: Indeks.

Swarjana A, 2013. Metodologi

Penelitian. Yogyakarta: Andi

Yuliastanti T (2014) Pola Asuh Dan

Perkembangan Personal Sosial Anak

Toddler. http://www.google.co.id.

diakses2 Februri 2019 